\title{
Association of Interleukin-17F 7488A/G and 7383A/G Polymorphisms With Rheumatoid Arthritis: A Meta-Analysis
}

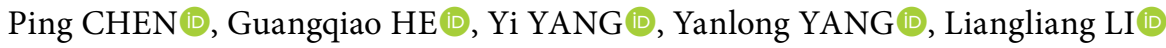 \\ Department of Rheumatology, Daping Hospital, The Third Affiliated Hospital of Third Military Medical University, Chongqing, China
}

\begin{abstract}
Objectives: This meta-analysis aims to summarize and estimate the relationship between rheumatoid arthritis (RA) susceptibility and two polymorphisms of interleukin-17F (IL-17F) 7488A/G and 7383A/G.

Materials and methods: PubMed, Embase and Web of Science were searched up to 01 July 2017. Case-control studies with genotype frequencies data for 7488A/G and 7383A/G were included. The pooled effects were calculated by fixed-effect model or random effects model.

Results: A total of seven publications with 1,409 RA patients and 1,303 controls were included in the present meta-analysis. The results indicated that $7488 \mathrm{~A} / \mathrm{G}$ was significantly associated with increased susceptibility to RA (GA vs. AA: odds ratio [OR] $=1.43,95 \%$ confidence interval [CI]: $1.07-1.90$, $p=0.02 ; G G$ vs. $A A: O R=3.22,95 \% C l: 1.54-6.74, p=0.002 ; G A+G G$ vs. $A A: O R=1.57,95 \%$ Cl: $1.02-2.42, p=0.04 ; G G$ vs. GA+AA: OR=3.05, 95\% Cl: $1.46-6.39$, $\mathrm{p}=0.003)$. In subgroup analysis, $7488 \mathrm{~A} / \mathrm{G}$ was a strong risk factor in Europeans but not in Americans or Africans. No significant association was found between $7383 \mathrm{~A} / \mathrm{G}$ and RA in overall population or ethnic subgroups by all genetic model comparisons.

Conclusion: This meta-analysis provided evidence that IL-17F 7488A/G polymorphism is associated with increased RA susceptibility, while no clear correlation was found between $7383 \mathrm{~A} / \mathrm{G}$ and RA.

Keywords: Interleukin-17F, polymorphism, rheumatoid arthritis, meta-analysis.
\end{abstract}

Rheumatoid arthritis (RA) is a common autoimmune disease that is associated with the destruction of affected joints by chronic inflammation and the infiltration of CD4+ T cells. ${ }^{1}$ Up to now, the etiology of RA remains not fully understood. However, it is believed that a complex interaction between genetic and environmental factors results in the initiation and development of RA..$^{2,3}$ Since the first genetic molecular human leukocyte antigen (HLA)-DRB1 was demonstrated to contribute to RA susceptibility, ${ }^{4}$ many more genetic factors were found to be associated with the pathogenesis of RA. ${ }^{5,6}$

Interleukin-17 (IL-17) is a proinflammatory cytokine family secreted by activated T cells. ${ }^{7}$ IL-17 consists of six family members: IL-17A, IL-17B, IL-17C, IL-17D, IL-17E, and IL-17F. ${ }^{8}$ Among them, IL-17A is the first discovered in 1993 by Rouvier et al., ${ }^{9}$ and the later studies disclosed that IL-17A played an important role in RA by aggravating the synovial inflammation and bone destruction. ${ }^{10}$ Like IL-17A, IL-17F, which shares strong homology with IL-17A, was expressed in synovial tissue and synoviocytes of RA and showed important functional and biological properties in the regulation of inflammatory reactions and immune responses. ${ }^{11,12}$ In 2010, Paradowska-Gorycka et al. ${ }^{13}$ initially investigated the two polymorphisms of IL-17F 7488A/G (rs763780) and 7383A/G (rs2397084) in RA in a

Received: April 21, 2018 Accepted: June 06, 2018 Published online: September 13, 2018

Correspondence: Liangliang Li, MD. Department of Rheumatology, Daping Hospital, The Third Affiliated Hospital of Third Military Medical University, 400042 Chongqing, China. Tel: 0086-2368757745 e-mail: liliangliang01@126.com 
Polish cohort. Although no significant association between the two variants and RA was found in this study, the following researches have proved that there was a clear correlation between IL-17F polymorphisms and RA susceptibility. ${ }^{14,15}$

However, it is undeniable that the results remained inconsistent among studies due to the instability of trend in different publications. For instance, the positive relationship between IL-17F 7488A/G and RA risk reported by Bogunia-Kubik et al. ${ }^{15}$ could not be replicated by Pawlik et al. ${ }^{16}$ even in the same population. It is necessary to carry out a comprehensive study to summarize those inconsistent results. Therefore, in this metaanalysis, we aimed to summarize and estimate the relationship between RA susceptibility and two polymorphisms of IL-17F 7488A/G and 7383A/G.

\section{MATERIALS AND METHODS}

This study was conducted at The Third Affiliated Hospital of Third Military Medical University, China between November 2016 and December 2017. PubMed, Web of Science and Embase online databases were systematically searched by two independent investigators to identify relevant publications up to 01 July 2017. The following key words and their combination were used: "Interleukin-17F OR IL-17F", "genetic polymorphisms OR polymorphism OR variant" and "rheumatoid arthritis OR RA". The title and abstract of each study were carefully reviewed. References list of relevant studies and reviews were also manually searched.

Eligible studies met the following criteria: (i) evaluation of the association between IL-17F polymorphisms and RA; (ii) studies focusing on human being with controls from healthy population; (iii) have detailed allelic data or genotype distribution frequencies of cases and controls. Exclusion criteria: (i) meeting, review, comment and duplication of previous publications; (ii) studies without detailed allelic or genotype data; (iii) studies that did not focus on IL-17F 7488A/G or $7383 \mathrm{~A} / \mathrm{G}$ polymorphism; (iv) family-based studies. Study selection was achieved by two independent investigators.

The following information was independently extracted by two authors: the name of the first author, year of publication, original country, the ethnicity of cases and controls, genotyping methods, specimen type, number of cases and controls, allele and genotype frequency of IL-17F $7488 \mathrm{~A} / \mathrm{G}$ and $7383 \mathrm{~A} / \mathrm{G}$ in cases and controls, Hardy-Weinberg equilibrium (HWE) in controls, and the criteria of RA. Two authors checked all the extracted data and had a discussion to reach consensus on any disagreement with a third author.

\section{Statistics analysis}

All statistical analyses were performed by Review Manager software version 5.2 and Stata software version 12.0 (StataCorp, College Station, TX, USA). Chi-square test was used to calculate the HWE in control group, and the HWE was considered a significant departure when $\mathrm{p}<0.05$. Odds ratios (ORs) and 95\% confidence intervals (CIs) were calculated to evaluate the strength of the association between IL-17F 7488A/G and $7383 \mathrm{~A} / \mathrm{G}$ polymorphism and susceptibility to RA. Meta-analyses were performed by allelic model (7488A/G: G vs. A; 7383A/G: $\mathrm{G}$ vs. A), heterozygote model (7488A/G: GA vs. AA; 7383A/G: GA vs. AA), homozygote model (7488A/G: GG vs. AA; 7383A/G: GG vs. AA), dominant model (7488A/G: GA+GG vs. AA; 7383A/G: $G A+G G$ vs. AA), recessive model (7488A/G: GG vs. GA+AA; 7383A/G: GG vs. GA+AA). Cochran's Q-statistic and I'statistic were used to evaluate the heterogeneity. The heterogeneity was considered to be significant when $\mathrm{I}^{2}>50 \%$ and/or $\mathrm{p}<0.1$. Random effects models or fixed-effect model was applied to pool the effect sizes depending on the heterogeneity. Sensitivity analysis was also performed to test the robustness of the pooled effects by omitting the stud deviated from HWE. Potential publication bias was assessed by Begg's funnel plot and Egger's regression test $(p<0.05$ was considered statistical publication bias).

\section{RESULTS}

Based on the search strategies, a total of 94 studies were identified from PubMed, Web of Science and Embase databases. Forty-seven were excluded by scanning titles and abstracts since they were reviews, meeting reports, letters or irrelevant to the present study. After reviewing the full texts 
of the remaining 11 publications, we excluded four reports as they either contained no key information on IL-17F 7488A/G or 7383A/G or were not case-control studies. Finally, seven studies including 1,409 RA patients and 1,303 controls were eligible for the present study. ${ }^{13-19}$ The flow chart of the literature research and study selection is shown in Figure 1. Among the included studies, all seven investigated the correlation between 7488A/G and RA susceptibility, but only four (containing 1,093 cases and 969 controls) researched 7383A/G and RA risk. ${ }^{13,14,16,19}$ Moreover, in the study of Louahchi et al., ${ }^{19}$ only allele data could be extracted. The main characteristics of these studies are shown in Table 1. Allele and genotype distributions of 7488A/G and 7383A/G are listed in Table 2.

We firstly analyzed the association between IL-17F 7488A/G polymorphism and the susceptibility to RA. A statistical test suggested that significant heterogeneity was present for the allelic model $\left(\mathrm{I}^{2}=69 \%, \mathrm{p}=0.004\right)$ and dominant model $\left(\mathrm{I}^{2}=53 \%, \mathrm{p}=0.060\right)$; therefore the random effects model was used in the two model analyses and fixed effects model was used in the other there model analyses. Significant associations between IL-17F 7488A/G

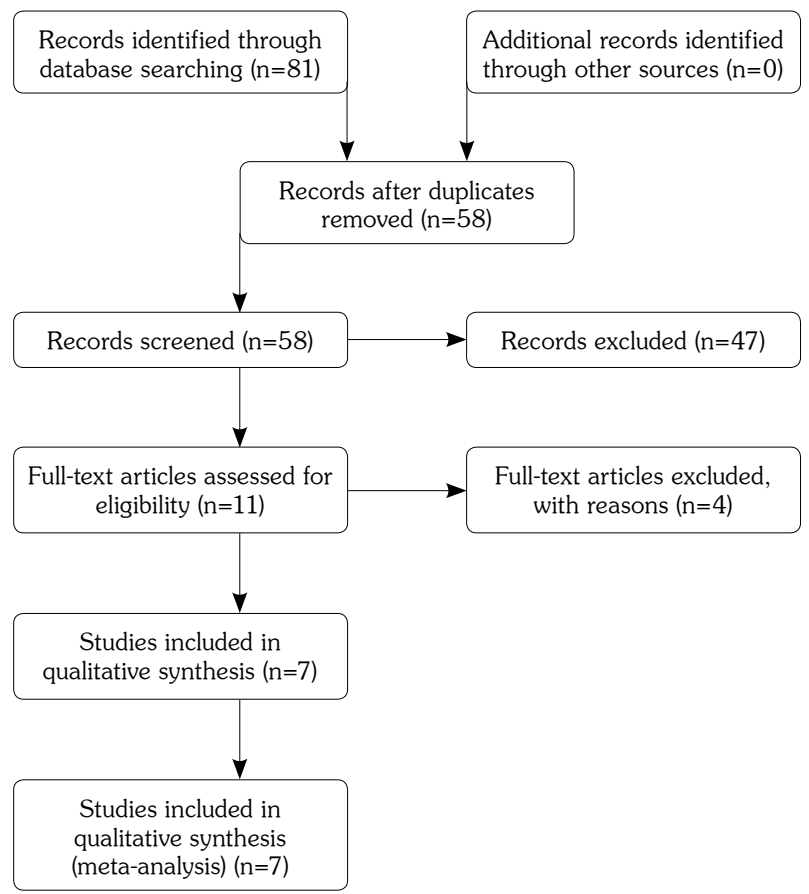

Figure 1. Flow chart of literature research and selection of included studies.

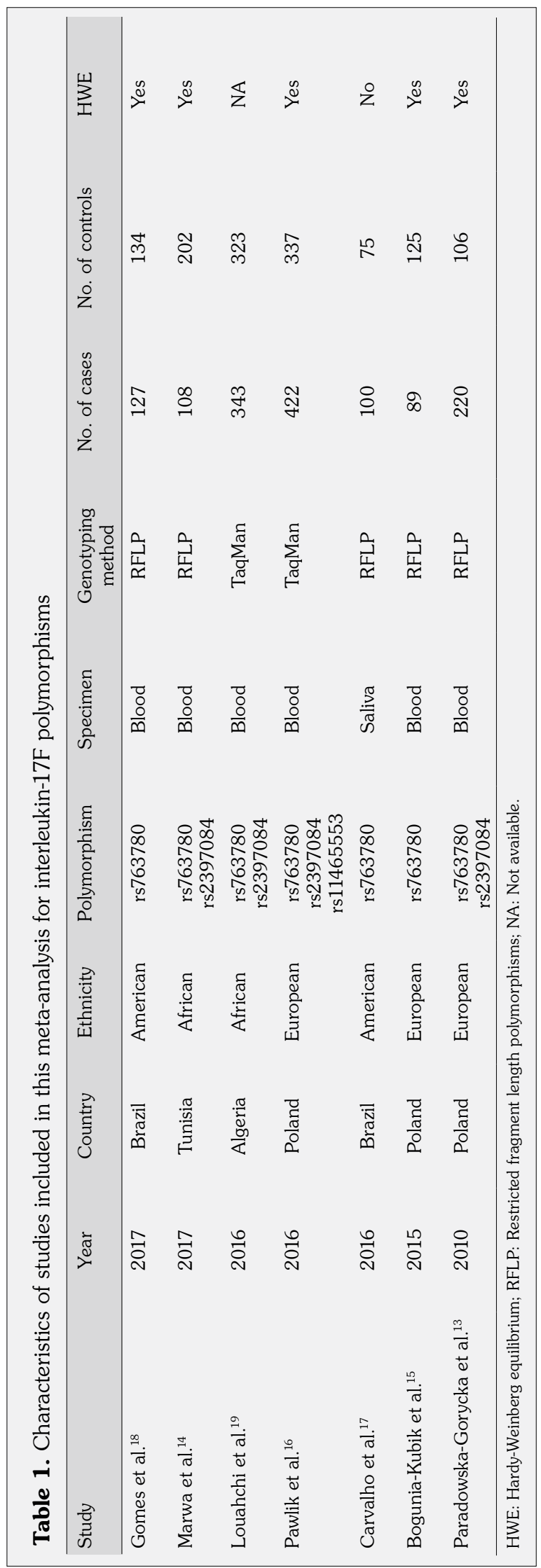


(a)

\begin{tabular}{|c|c|c|c|c|c|c|c|c|c|}
\hline Studv or Subgroup & $\begin{array}{l}\text { Experim } \\
\text { Events }\end{array}$ & $\begin{array}{l}\text { ntal } \\
\text { Total }\end{array}$ & $\begin{array}{l}\text { Contr } \\
\text { Events }\end{array}$ & $\begin{array}{l}\text { ol } \\
\text { Total }\end{array}$ & Weight & $\begin{array}{c}\text { Odds Ratio } \\
\text { M-H. Fixed, 95\% Cl }\end{array}$ & $\begin{array}{r}\text { Odd: } \\
\text { M-H, Fix }\end{array}$ & $\begin{array}{l}\text { Is Ratio } \\
\text { xed, } 95 \% \mathrm{Cl}\end{array}$ & \\
\hline Bogunia-Kubik 2015 & 9 & 73 & 0 & 114 & $4.0 \%$ & $33.73[1.93,589.04]$ & & & \\
\hline Carvalho 2016 & 3 & 90 & 3 & 72 & $37.4 \%$ & $0.79[0.16,4.05]$ & & & \\
\hline Gomes 2017 & 0 & 119 & 1 & 121 & $17.2 \%$ & $0.34[0.01,8.33]$ & & & \\
\hline Manwa 2017 & 8 & 72 & 3 & 140 & $21.0 \%$ & $5.71[1.47,22.23]$ & & & \\
\hline Paradowska-Gorycka 2010 & 1 & 196 & 0 & 98 & $7.7 \%$ & $1.51[0.06,37.44]$ & & & \\
\hline Pawlik 2016 & 2 & 387 & 1 & 319 & $12.7 \%$ & $1.65[0.15,18.30]$ & & & \\
\hline Total (95\% Cl) & & 937 & & 864 & $100.0 \%$ & $3.22[1.54,6.74]$ & & & \\
\hline Total events & 23 & & 8 & & & & & & \\
\hline \multicolumn{7}{|c|}{$\begin{array}{l}\text { Heterogeneity: } \text { Chi }^{2}=8.52, d f=5(P=0.13) ; I^{2}=41 \% \\
\text { Test for overall effect: } Z=3.10(P=0.002)\end{array}$} & $\begin{array}{cc}0.01 & 0.1 \\
\text { Favors [experimental] }\end{array}$ & $\begin{array}{l}i \frac{10}{\text { Favors [control] }} \\
\end{array}$ & 100 \\
\hline
\end{tabular}

(b)

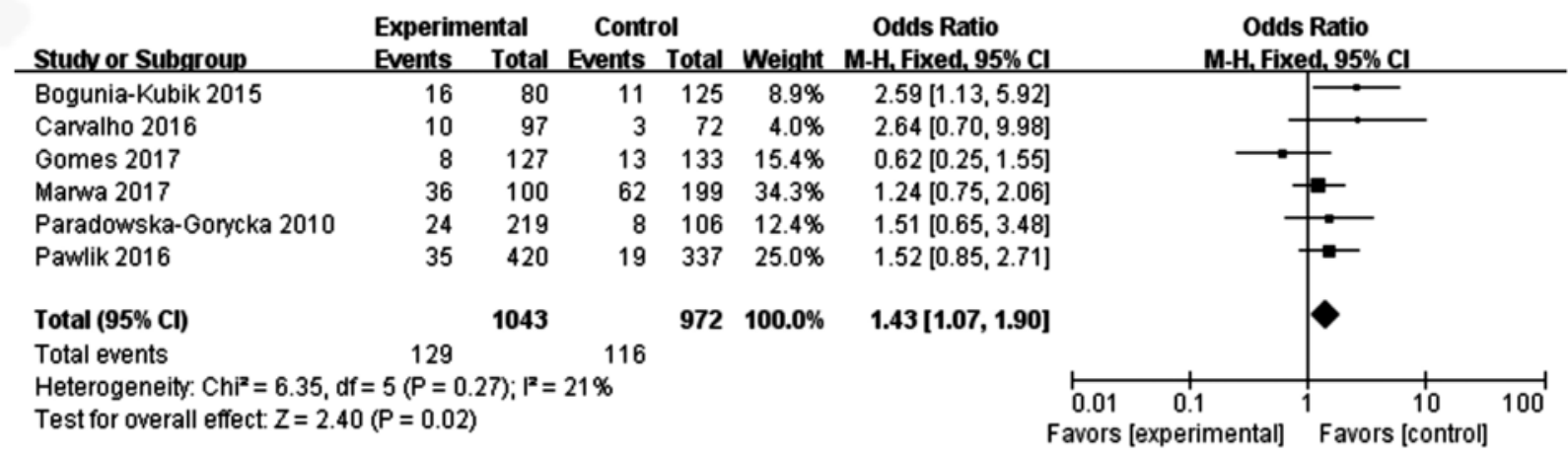

(c)

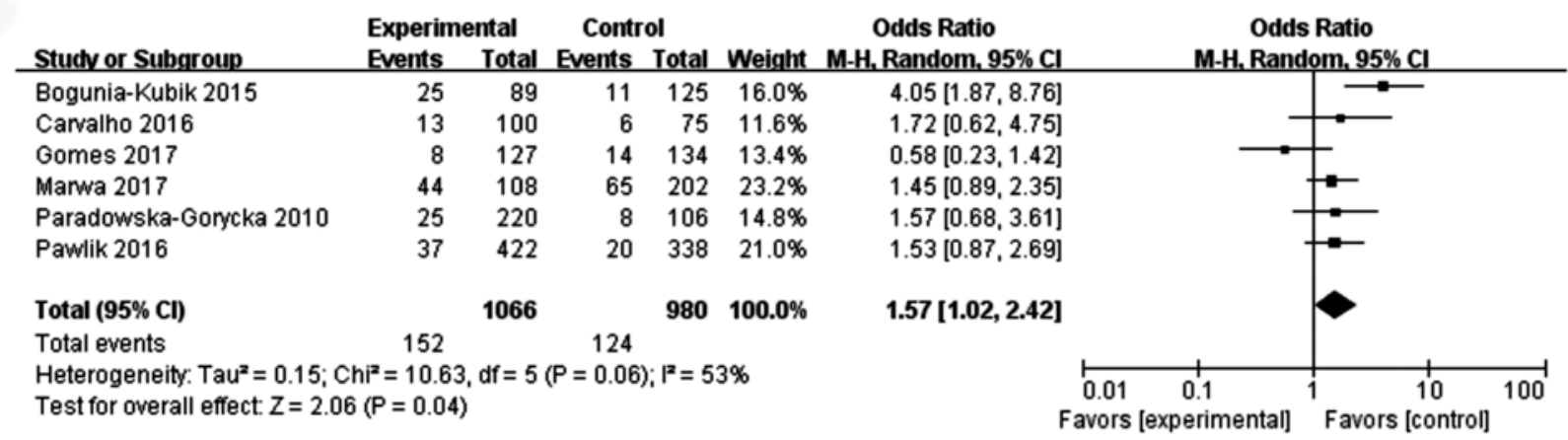

(d)

\begin{tabular}{|c|c|c|c|c|c|c|c|c|c|c|}
\hline Study or Subgroup & \multicolumn{2}{|c|}{ Experimental } & \multicolumn{2}{|c|}{ Control } & Weight & $\begin{array}{c}\text { Odds Ratio } \\
\text { M-H. Fixed, } 95 \% \mathrm{Cl}\end{array}$ & \multicolumn{4}{|c|}{$\begin{array}{c}\text { Odds Ratio } \\
\text { M-H. Fixed, } 95 \% \mathrm{Cl}\end{array}$} \\
\hline Bogunia-Kubik 2015 & 9 & 89 & 0 & 125 & $4.2 \%$ & $29.62[1.70,515.97]$ & & & & \\
\hline Carvalho 2016 & 3 & 100 & 3 & 75 & $37.5 \%$ & $0.74[0.15,3.78]$ & & & & \\
\hline Gomes 2017 & 0 & 127 & 1 & 134 & $16.4 \%$ & $0.35[0.01,8.65]$ & & & & \\
\hline Marwa 2017 & 8 & 108 & 3 & 202 & $21.8 \%$ & $5.31[1.38,20.44]$ & & & & \\
\hline Paradowska-Gorycka 2010 & 1 & 220 & 0 & 106 & $7.6 \%$ & $1.46[0.06,36.03]$ & & & & \\
\hline Pawlik 2016 & 2 & 422 & 1 & 338 & $12.5 \%$ & $1.60[0.14,17.77]$ & & & & \\
\hline Total $(95 \% \mathrm{Cl})$ & & 1066 & & 980 & $100.0 \%$ & $3.05[1.46,6.39]$ & & & & \\
\hline Total events & 23 & & 8 & & & & & & & \\
\hline $\begin{array}{l}\text { Heterogeneity: } \mathrm{Chi}^{2}=8.20,0 \\
\text { Test for overall effect: } \mathrm{Z}=2.9\end{array}$ & $\begin{array}{l}=5(P=0 \\
(P=0.00\end{array}$ & 5); $1^{2}=$ & $9 \%$ & & & & $\begin{array}{cc}0.01 & 0.1 \\
\text { avors [experimental] }\end{array}$ & ${ }^{1}$ Favors [c & $\begin{array}{l}10 \\
\text { control] }\end{array}$ & 100 \\
\hline
\end{tabular}

Figure 2. Forest plots of meta-analysis of interleukin-17F $7488 \mathrm{~A} / \mathrm{G}$ and rheumatoid arthritis in overall population. A. Heterozygote model (GA vs. AA); B. Homozygote model (GG vs. AA); C. Dominant model (GG+GA vs. AA); D. Recessive model (GG vs. GA+AA). CI: Confidence interval. 
Table 2. Allele and genotype information of interleukin-17F 7488A/G and 7383A/G polymorphisms in rheumatoid arthritis cases and controls

\begin{tabular}{|c|c|c|c|c|c|c|c|c|c|c|c|}
\hline \multirow[t]{2}{*}{ Study } & \multirow[t]{2}{*}{ Polymorphism } & \multicolumn{5}{|c|}{ Cases } & \multicolumn{5}{|c|}{ Controls } \\
\hline & & G & A & GG & GA & AA & G & A & GG & GA & AA \\
\hline Marwa et al. ${ }^{14}$ & $\begin{array}{c}\text { 7488A/G } \\
(\mathrm{rs} 763780)\end{array}$ & 52 & 164 & 8 & 36 & 64 & 68 & 336 & 3 & 62 & 137 \\
\hline Gomes da Silva et al. ${ }^{18}$ & $\begin{array}{c}\text { 7488A/G } \\
(\mathrm{rs} 763780)\end{array}$ & 8 & 246 & 0 & 8 & 119 & 15 & 253 & 1 & 13 & 120 \\
\hline Louahchi et al. ${ }^{19}$ & $\begin{array}{c}\text { 7488A/G } \\
\text { (rs763780) }\end{array}$ & 42 & 644 & & & & 38 & 608 & & & \\
\hline Pawlik et al. ${ }^{16}$ & $\begin{array}{c}\text { 7488A/G } \\
\text { (rs763780) }\end{array}$ & 39 & 805 & 2 & 35 & 385 & 21 & 655 & 1 & 19 & 318 \\
\hline Carvalho et al. ${ }^{17}$ & $\begin{array}{c}\text { 7488A/G } \\
(\mathrm{rs} 763780)\end{array}$ & 16 & 184 & 3 & 10 & 87 & 9 & 141 & 3 & 3 & 69 \\
\hline Bogunia-Kubik et al. ${ }^{15}$ & $\begin{array}{c}\text { 7488A/G } \\
\text { (rs763780) }\end{array}$ & 34 & 144 & 9 & 16 & 64 & 11 & 239 & 0 & 11 & 114 \\
\hline Paradowska-Gorycka et al. ${ }^{13}$ & $\begin{array}{c}\text { 7488A/G } \\
(\mathrm{rs} 763780)\end{array}$ & 26 & 414 & 1 & 24 & 195 & 8 & 204 & 0 & 8 & 98 \\
\hline Gomes da Silva et al. ${ }^{18}$ & $\begin{array}{c}\text { 7383A/G } \\
\text { (rs2397084) }\end{array}$ & 54 & 162 & 5 & 44 & 59 & 50 & 354 & 4 & 42 & 156 \\
\hline Louahchi et al. ${ }^{19}$ & $\begin{array}{c}\text { 7383A/G } \\
\text { (rs2397084) }\end{array}$ & 44 & 642 & & & & 41 & 605 & & & \\
\hline Pawlik et al. ${ }^{16}$ & $\begin{array}{c}\text { 7383A/G } \\
\text { (rs2397084) }\end{array}$ & 87 & 757 & 2 & 83 & 337 & 77 & 599 & 7 & 63 & 268 \\
\hline Paradowska-Gorycka et al. ${ }^{13}$ & $\begin{array}{c}\text { 7383A/G } \\
(\mathrm{rs} 2397084)\end{array}$ & 44 & 396 & 3 & 38 & 179 & 22 & 190 & 0 & 22 & 84 \\
\hline
\end{tabular}

polymorphism and RA risk were identified in the heterozygote model (GA vs. AA: OR=1.43, 95\% CI: 1.07-1.90, $\mathrm{p}=0.02$ ), homozygote model (GG vs. $\mathrm{AA}: \mathrm{OR}=3.22,95 \% \mathrm{CI}$ : $1.54-6.74, \mathrm{p}=0.002)$, dominant model (GA+GG vs. AA: $O R=1.57,95 \%$ $\mathrm{CI}$ : 1.02-2.42, $\mathrm{p}=0.04)$, and recessive model (GG vs. GA+AA: $\mathrm{OR}=3.05$, 95\% CI: 1.46-6.39, $\mathrm{p}=0.003$ ) (Figure 2). In the allelic model analysis, there was no significant association between $7488 \mathrm{~A} / \mathrm{G}$ and RA ( $\mathrm{G}$ vs. A: $\mathrm{OR}=1.49,95 \%$ CI: 0.98-2.27, $\mathrm{p}=0.06)$. However, a trend of increased risk could be seen (Figure 2).

Next, subgroup analysis was carried out by stratifying patients into Europeans, Americans, and Africans. Intriguingly, close correlation between 7488A/G and RA in Europeans was observed by all genetic models ( $G$ vs. A: $O R=2.29,95 \% C I$ : 1.05-5.02, $\mathrm{p}=0.04$; $\mathrm{GA}$ vs. $\mathrm{AA}: \mathrm{OR}=1.72,95 \%$ CI: 1.14-2.61, $\mathrm{p}=0.01$; $\mathrm{GG}$ vs. $\mathrm{AA}: \mathrm{OR}=6.84$, 95\% CI: 1.66-28.26, $\mathrm{p}=0.008$; $\mathrm{GA}+\mathrm{GG}$ vs. AA: $\mathrm{OR}=2.08,95 \% \mathrm{CI}: 1.13-3.85, \mathrm{p}=0.02$; $\mathrm{GG}$ vs. $\mathrm{GA}+\mathrm{AA}: \mathrm{OR}=6.42$, 95\% CI: 1.54-26.74, $\mathrm{p}=0.01$ ). However, 7488A/G was not associated with RA in Americans or Africans (Table 3).
Random effects model was used in the analyses of allelic model, homozygote model, dominant model, and recessive model due to the statistically significant heterogeneity, whereas fixed-effect model was used in heterozygote model $\left(\mathrm{I}^{2}=43 \%\right.$, $p=0.17)$. The results indicated that there was no significant association between IL-17F 7383A/G polymorphism and RA susceptibility in overall

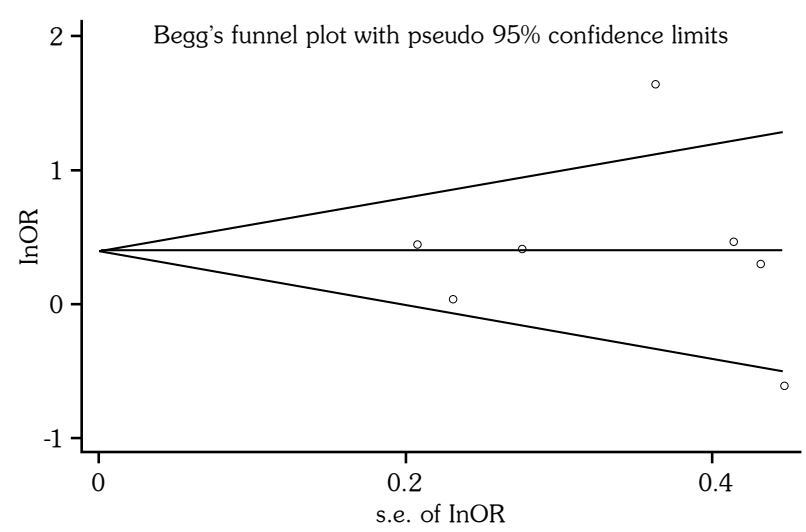

Figure 3. Begg's funnel plot for publication bias of interleukin-17F 7488A/G for overall comparison ( $G$ vs. A). 
Table 3. Summary of association between interleukin-17F 7488A/G and rheumatoid arthritis susceptibility

\begin{tabular}{|c|c|c|c|c|c|c|c|c|c|}
\hline \multirow[b]{2}{*}{ Comparsion } & \multirow[b]{2}{*}{ Ethnicity } & \multirow[b]{2}{*}{$\begin{array}{l}\text { No. of } \\
\text { study }\end{array}$} & \multicolumn{3}{|c|}{ Test of association } & \multirow[b]{2}{*}{ Model } & \multicolumn{2}{|c|}{ Test of heterogeneity } & \multirow[b]{2}{*}{$\begin{array}{l}\text { Egger's test } \\
\text { (p-value) }\end{array}$} \\
\hline & & & OR & $95 \% \mathrm{CI}$ & P-value & & $\mathrm{P}$-value & $\mathrm{I}^{2}(\%)$ & \\
\hline $\begin{array}{l}\text { G vs. A } \\
\text { (Allelic model) }\end{array}$ & $\begin{array}{l}\text { Overall } \\
\text { European } \\
\text { American } \\
\text { African }\end{array}$ & $\begin{array}{l}7 \\
3 \\
2 \\
2\end{array}$ & $\begin{array}{l}1.49 \\
2.29 \\
0.87 \\
1.30\end{array}$ & $\begin{array}{l}0.98-2.27 \\
1.05-5.02 \\
0.36-2.12 \\
0.96-1.76\end{array}$ & $\begin{array}{l}0.06 \\
\mathbf{0 . 0 4} \\
0.76 \\
0.09\end{array}$ & $\begin{array}{l}R \\
R \\
R \\
F\end{array}$ & $\begin{array}{l}0.004 \\
0.020 \\
0.760 \\
0.190\end{array}$ & $\begin{array}{l}69 \\
75 \\
53 \\
42\end{array}$ & $\begin{array}{c}0.707 \\
0.903 \\
\text { NA } \\
\text { NA }\end{array}$ \\
\hline $\begin{array}{l}\text { GA vs. AA } \\
\text { (Heterozygote } \\
\text { model) }\end{array}$ & $\begin{array}{l}\text { Overall } \\
\text { European } \\
\text { American } \\
\text { African }\end{array}$ & $\begin{array}{l}6 \\
3 \\
2 \\
1\end{array}$ & $\begin{array}{l}1.43 \\
1.72 \\
1.18 \\
\text { NA }\end{array}$ & $\begin{array}{l}1.07-1.90 \\
1.14-2.61 \\
0.29-4.85\end{array}$ & $\begin{array}{l}\mathbf{0 . 0 2} \\
\mathbf{0 . 0 1} \\
0.82\end{array}$ & $\begin{array}{l}\mathrm{F} \\
\mathrm{F} \\
\mathrm{R}\end{array}$ & $\begin{array}{l}0.270 \\
0.550 \\
0.080\end{array}$ & $\begin{array}{c}21 \\
0 \\
68\end{array}$ & $\begin{array}{c}0.907 \\
0.910 \\
\text { NA }\end{array}$ \\
\hline $\begin{array}{l}\text { GG vs. AA } \\
\text { (Homozygote } \\
\text { model) }\end{array}$ & $\begin{array}{l}\text { Overall } \\
\text { European } \\
\text { American } \\
\text { African }\end{array}$ & $\begin{array}{l}6 \\
3 \\
2 \\
1\end{array}$ & $\begin{array}{l}3.22 \\
6.84 \\
0.65 \\
\text { NA }\end{array}$ & $\begin{array}{c}1.54-6.74 \\
1.66-28.26 \\
0.16-2.71\end{array}$ & $\begin{array}{c}\mathbf{0 . 0 0 2} \\
\mathbf{0 . 0 0 8} \\
0.55\end{array}$ & $\begin{array}{l}\mathrm{F} \\
\mathrm{F} \\
\mathrm{F}\end{array}$ & $\begin{array}{l}0.130 \\
0.180 \\
0.640\end{array}$ & $\begin{array}{c}41 \\
41 \\
0\end{array}$ & $\begin{array}{l}0.474 \\
0.943 \\
\text { NA }\end{array}$ \\
\hline $\begin{array}{l}\text { GG + GA vs.AA } \\
\text { (Dominant } \\
\text { model) }\end{array}$ & $\begin{array}{l}\text { Overall } \\
\text { European } \\
\text { American } \\
\text { African }\end{array}$ & $\begin{array}{l}6 \\
3 \\
2 \\
1\end{array}$ & $\begin{array}{l}1.57 \\
2.08 \\
0.97 \\
\text { NA }\end{array}$ & $\begin{array}{l}1.02-2.42 \\
1.13-3.85 \\
0.33-2.83\end{array}$ & $\begin{array}{l}\mathbf{0 . 0 4} \\
\mathbf{0 . 0 2} \\
0.96\end{array}$ & $\begin{array}{l}R \\
R \\
R\end{array}$ & $\begin{array}{l}0.060 \\
0.110 \\
0.120\end{array}$ & $\begin{array}{l}53 \\
55 \\
60\end{array}$ & $\begin{array}{c}0.609 \\
0.862 \\
\text { NA }\end{array}$ \\
\hline $\begin{array}{l}\text { GG vs. GA + AA } \\
\text { (Recessive } \\
\text { model) }\end{array}$ & $\begin{array}{l}\text { Overall } \\
\text { European } \\
\text { American } \\
\text { African }\end{array}$ & $\begin{array}{l}6 \\
3 \\
2 \\
1\end{array}$ & $\begin{array}{l}3.05 \\
6.42 \\
0.62 \\
\text { NA }\end{array}$ & $\begin{array}{c}1.46-6.39 \\
1.54-26.74 \\
0.15-2.60\end{array}$ & $\begin{array}{c}\mathbf{0 . 0 0 3} \\
\mathbf{0 . 0 1} \\
0.52\end{array}$ & $\begin{array}{l}F \\
F \\
F\end{array}$ & $\begin{array}{l}0.150 \\
0.200 \\
0.680\end{array}$ & $\begin{array}{c}39 \\
37 \\
0\end{array}$ & $\begin{array}{c}0.486 \\
0.946 \\
\text { NA }\end{array}$ \\
\hline
\end{tabular}

population by any genetic model ( $G$ vs. A: $\mathrm{OR}=1.20$, 95\% CI: 0.76-1.89, $\mathrm{p}=0.44$; GA vs. AA: $\mathrm{OR}=1.04,95 \%$ CI: 0.77-1.40, $\mathrm{p}=0.82$; GG vs. AA: $\mathrm{OR}=1.22$, 95\% CI: 0.17-8.84, $\mathrm{p}=0.84 ; \mathrm{GA}+\mathrm{GG}$ vs. $\mathrm{AA}: \mathrm{OR}=1.33,95 \% \mathrm{CI}: 0.65-2.71, \mathrm{p}=0.43$; $\mathrm{GG}$ vs. $\mathrm{GA}+\mathrm{AA}: \mathrm{OR}=1.07,95 \% \mathrm{CI}: 0.18-6.41$, $p=0.94$ ) or in subgroup analysis based on ethnicity (data not shown).

Sensitivity analysis was conducted to identify the studies that have potential influence on the pooled effects. We analyzed the controls of each study for the fitness in the HWE. The study of Carvalho et al. ${ }^{17}$ was deviated from HWE. In addition, the HWE of Louahchi et al. ${ }^{19}$ was not available for the lack of genotype frequency data. Therefore, sensitivity analysis was performed by deleting the two studies in all model analyses. The results from the remaining studies showed that the pooled effects were not significantly altered by the two studies. Begg's funnel plot and Egger's regression test were used to evaluate the publication bias for IL-17F 7488A/G polymorphism studies. However, no significant publication bias was identified in overall comparisons (Figure 3). As for the publication bias of IL-17F 7383A/G analyses, the analysis of publication bias was not performed due to the limited number of eligible studies.

\section{DISCUSSION}

It has been previously reported that IL-17F polymorphisms were excellent candidates serving as genetic risk factor in various inflammatory diseases including inflammatory bowel disease, ${ }^{20}$ Behcet's disease ${ }^{21}$ ulcerative colitis ${ }^{22}$ and asthma, ${ }^{23}$ as well as RA. ${ }^{15}$ However, the results from recent studies were inconsistent. In the present metaanalysis, we included seven case-control studies containing 1,409 RA patients and 1,303 controls for IL-17F 7488A/G, four of which containing 1,093 cases and 969 controls for IL-17F 7383A/G to pool the effects of the two polymorphisms on RA susceptibility. The results showed that IL-17F 7488A/G was significantly associated with RA as proved by heterozygote model (GA vs. AA), homozygote model (GG vs. AA), dominant model (GG+GA vs. AA) and recessive model ( $G G$ vs. $G A+A A$ ), which indicated that the GG and/or GA genotype holders have a higher risk for developing RA. Moreover, 7488A/G variant might correlate with RA risk in an ethnic-specific 
manner, specifically in Europeans but not in Americans or Africans. However, no evidence was found for the relationship between IL-17F 7383A/G and RA susceptibility in any genetic models either in overall or subgroup population.

As a chronic inflammatory disease, RA was affected by numerous cytokines, which initiate and maintain the pathological response in joints. A growing number of studies have shown the critical role of IL-17F in RA pathogenesis and the significant association of IL-17F polymorphisms with RA susceptibility. ${ }^{12,14,24}$ IL-17F shared about $50 \%$ homology of amino acid sequence with IL-17A. ${ }^{25}$ In the synovial fluid and tissue of RA patients, the expression level IL-17 was markedly upregulated compared with normal controls, which regulate the turnover of matrix and promote cartilage destruction. ${ }^{26,27}$ Recently, three polymorphisms of IL-17F in RA have been studied. ${ }^{14,16}$ In the present study, we focused on the association of the two variants IL-17F 7488A/G, which changes amino acid 161 in exon 3 from histidine (A allele) to arginine ( $\mathrm{G}$ allele), and $7383 \mathrm{~A} / \mathrm{G}$, which leads to the changes of amino from glutamic acid (A allele) to glycine ( $G$ allele), with RA risk. Both variants might influence molecular structure and biological function of the protein. For example, the substitution of histidine to arginine of IL-17F 7488A/G had impact on the affinity of binding with IL-17F receptor. ${ }^{28}$

Although several studies have investigated the correlation between IL-17F polymorphisms and RA susceptibility, the results were scattered and discrepant. In our work, we collected the current evidence and found that IL-17F 7488A/G was indeed significantly associated with increased RA risk. This was in line with a previous meta-analysis by Lee and Bae, ${ }^{29}$ which enrolled four and two studies for IL-17F 7488A/G and 7383A/G, respectively, demonstrating that $7488 \mathrm{~A} / \mathrm{G}$ but not $7383 \mathrm{~A} / \mathrm{G}$ was closely correlated with RA development in Caucasians, which mainly consist of Europeans. In addition, they also found that the levels of circulating IL-17 in RA patients were markedly higher than that in healthy controls. Another meta-analysis including four studies also observed a positive association between IL-17F 7488A/G and RA susceptibility. ${ }^{30}$ However, caution should be taken for the conclusion of this meta-analysis since a study on osteoarthritis was included in the RA group. ${ }^{31}$
There were several strengths of our work. First of all, we performed the present study based on a larger cohort including 1,409 RA patients and 1,303 controls compared to previous meta-analyses which helped to strengthen the evidence that IL-17F 7488A/G was significantly associated with RA. Compared with the previous meta-analyses, a greater number of studies containing different publications were included. Furthermore; subgroup analysis, sensitivity analysis and publications bias test were also carried out. Moreover, a strict inclusion and exclusion criteria were implemented to ensure the quality of included studies and reliability of the results. Finally, selection bias was well-controlled via literature research and no publication bias was identified by Begg's funnel plot and Egger's test.

Nevertheless, several limitations should be considered in the present study. Firstly, statistical heterogeneity was observed in some comparisons involving both IL-17F 7488A/G and $7383 \mathrm{~A} / \mathrm{G}$ polymorphisms. This could not be effectively eliminated by subgroup and sensitivity analysis, and therefore might partially influence the robustness of the results. Additional details are needed to evaluate the sources of the heterogeneity such as sample size, age of patients and genotyping methods. Secondly, there was one study derived from HWE and one without HWE inflammation. Although the pooled effects were not significantly influenced by the two studies, potential uncertainty factors may be present in the pooled efficiency. Thirdly, the number of original studies and patients were limited, particularly for $7383 \mathrm{~A} / \mathrm{G}$ polymorphism, which may cover the positive correlation between $7383 \mathrm{~A} / \mathrm{G}$ and RA. To this issue, additional case-control studies with high quality are needed to further disclose the association between 7383A/G and RA susceptibility.

In conclusion, despite the limitations above, our results strongly suggested that IL-17F 7488A/G polymorphism was significantly associated with a higher risk of RA in overall population and subgroup of Europeans, while no clear correlation between $7383 \mathrm{~A} / \mathrm{G}$ and RA was observed by the current available evidence. Further well-designed studies with larger sample sizes and ethnic groups are required to strengthen the results of the current study. 


\section{Declaration of conflicting interests}

The authors declared no conflicts of interest with respect to the authorship and/or publication of this article.

\section{Funding}

The authors received no financial support for the research and/or authorship of this article.

\section{REFERENCES}

1. Lillegraven S, van der Heijde D, Uhlig T, Kvien TK, Haavardsholm EA. What is the clinical relevance of erosions and joint space narrowing in RA? Nat Rev Rheumatol 2012;8:117-20.

2. MacGregor AJ, Snieder H, Rigby AS, Koskenvuo M, Kaprio J, Aho K, et al. Characterizing the quantitative genetic contribution to rheumatoid arthritis using data from twins. Arthritis Rheum 2000;43:30-7.

3. Barton A, Thomson W, Ke X, Eyre S, Hinks A, Bowes $\mathrm{J}$, et al. Re-evaluation of putative rheumatoid arthritis susceptibility genes in the post-genome wide association study era and hypothesis of a key pathway underlying susceptibility. Hum Mol Genet 2008; 17:2274-9.

4. Newton JL, Harney SM, Wordsworth BP, Brown MA. A review of the $\mathrm{MHC}$ genetics of rheumatoid arthritis. Genes Immun 2004;5:151-7.

5. Crispín JC, Tsokos GC. IL-17 in systemic lupus erythematosus. J Biomed Biotechnol 2010;2010:943254.

6. García-Bermúdez M, López-Mejías R, GonzálezJuanatey C, Castañeda S, Miranda-Filloy JA, Blanco $\mathrm{R}$, et al. Association of the methionine sulfoxide reductase A rs10903323 gene polymorphism with cardiovascular disease in patients with rheumatoid arthritis. Scand J Rheumatol 2012;41:350-3.

7. Paradowska A, Masliniski W, Grzybowska-Kowalczyk A, Lacki J. The function of interleukin 17 in the pathogenesis of rheumatoid arthritis. Arch Immunol Ther Exp (Warsz) 2007;55:329-34.

8. van den Berg WB, Miossec P. IL-17 as a future therapeutic target for rheumatoid arthritis. Nat Rev Rheumatol 2009;5:549-53.

9. Rouvier E, Luciani MF, Mattéi MG, Denizot F, Golstein P. CTLA-8, cloned from an activated T cell, bearing AU-rich messenger RNA instability sequences, and homologous to a herpesvirus saimiri gene. J Immunol 1993;150:5445-56.

10. Ruddy MJ, Wong GC, Liu XK, Yamamoto H, Kasayama $\mathrm{S}$, Kirkwood KL, et al. Functional cooperation between interleukin-17 and tumor necrosis factor-alpha is mediated by CCAAT/enhancer-binding protein family members. J Biol Chem 2004;279:2559-67.

11. Reynolds JM, Angkasekwinai P, Dong C. IL-17 family member cytokines: regulation and function in innate immunity. Cytokine Growth Factor Rev 2010;21:413-23.
12. Hymowitz SG, Filvaroff EH, Yin JP, Lee J, Cai L, Risser P, et al. IL-17s adopt a cystine knot fold: structure and activity of a novel cytokine, IL-17F, and implications for receptor binding. EMBO J 2001;20:5332-41.

13. Paradowska-Gorycka A, Wojtecka-Lukasik E, Trefler J, Wojciechowska B, Lacki JK, Maslinski S. Association between IL-17F gene polymorphisms and susceptibility to and severity of rheumatoid arthritis (RA). Scand J Immunol 2010;72:134-41.

14. Marwa OS, Kalthoum T, Wajih K, Kamel $\mathrm{H}$. Association of IL17A and IL17F genes with rheumatoid arthritis disease and the impact of genetic polymorphisms on response to treatment. Immunol Lett 2017;183:24-36.

15. Bogunia-Kubik K, Swierkot J, Malak A, Wysoczanska B, Nowak B, Bialowas K, et al. IL-17A, IL-17F and IL-23R Gene Polymorphisms in Polish Patients with Rheumatoid Arthritis. Arch Immunol Ther Exp (Warsz) 2015;63:215-21.

16. Pawlik A, Kotrych D, Malinowski D, Dziedziejko V, Czerewaty M, Safranow K. IL17A and IL17F gene polymorphisms in patients with rheumatoid arthritis. BMC Musculoskelet Disord 2016;17:208.

17. Carvalho $\mathrm{CN}$, do Carmo RF, Duarte AL, Carvalho AA, Leão JC, Gueiros LA. IL-17A and IL-17F polymorphisms in rheumatoid arthritis and Sjögren's syndrome. Clin Oral Investig 2016;20:495-502.

18. Gomes da Silva IIF, Angelo HD, Rushansky E, Mariano MH, Maia MMD, de Souza PRE. Interleukin (IL)-23 Receptor, IL-17A and IL-17F Gene Polymorphisms in Brazilian Patients with Rheumatoid Arthritis. Arch Immunol Ther Exp (Warsz) 2017;65:537-43.

19. Louahchi S, Allam I, Berkani L, Boucharef A, Abdesemed A, Khaldoun N, et al. Association study of single nucleotide polymorphisms of IL23R and IL17 in rheumatoid arthritis in the Algerian population. Acta Reumatol Port 2016;41:151-7.

20. Seiderer J, Elben I, Diegelmann J, Glas J, Stallhofer J, Tillack C, et al. Role of the novel Th17 cytokine IL-17F in inflammatory bowel disease (IBD): upregulated colonic IL-17F expression in active Crohn's disease and analysis of the IL17F p.His161Arg polymorphism in IBD. Inflamm Bowel Dis 2008;14:437-45.

21. Jang WC, Nam YH, Ahn YC, Lee SH, Park $\mathrm{SH}$, Choe JY, et al. Interleukin-17F gene polymorphisms in Korean patients with Behçet's disease. Rheumatol Int 2008;29:173-8.

22. Arisawa T, Tahara T, Shibata T, Nagasaka M, Nakamura M, Kamiya $\mathrm{Y}$, et al. The influence of polymorphisms of interleukin-17A and interleukin-17F genes on the susceptibility to ulcerative colitis. J Clin Immunol 2008;28:44-9.

23. Kawaguchi M, Takahashi D, Hizawa N, Suzuki S, Matsukura S, Kokubu F, et al. IL-17F sequence variant (His161Arg) is associated with protection against asthma and antagonizes wild-type IL-17F activity. J Allergy Clin Immunol 2006;117:795-801. 
24. Hot A, Miossec P. Effects of interleukin (IL)-17A and IL-17F in human rheumatoid arthritis synoviocytes. Ann Rheum Dis 2011;70:727-32.

25. Kolls JK, Lindén A. Interleukin-17 family members and inflammation. Immunity 2004;21:467-76.

26. Li N, Wang JC, Liang TH, Zhu MH, Wang JY, Fu $\mathrm{XL}$, et al. Pathologic finding of increased expression of interleukin-17 in the synovial tissue of rheumatoid arthritis patients. Int J Clin Exp Pathol 2013;6:1375-9.

27. Moran EM, Mullan R, McCormick J, Connolly M, Sullivan O, Fitzgerald $\mathrm{O}$, et al. Human rheumatoid arthritis tissue production of IL-17A drives matrix and cartilage degradation: synergy with tumour necrosis factor-alpha, Oncostatin $\mathrm{M}$ and response to biologic therapies. Arthritis Res Ther 2009;11:R113.

28. Hizawa N, Kawaguchi M, Huang SK, Nishimura M.
Role of interleukin-17F in chronic inflammatory and allergic lung disease. Clin Exp Allergy 2006;36:1109-14.

29. Lee YH, Bae SC. Associations between circulating IL-17 levels and rheumatoid arthritis and between IL-17 gene polymorphisms and disease susceptibility: a meta-analysis. Postgrad Med J 2017;93:465-71.

30. Eskandari-Nasab E, Moghadampour M, Tahmasebi A. Meta-Analysis of Risk Association Between Interleukin17A and F Gene Polymorphisms and Inflammatory Diseases. J Interferon Cytokine Res 2017;37:165-74.

31. Han L, Lee HS, Yoon JH, Choi WS, Park YG, Nam SW, et al. Association of IL-17A and IL-17F single nucleotide polymorphisms with susceptibility to osteoarthritis in a Korean population. Gene 2014;533:119-22. 